\title{
Society's Books of Note
}

\section{May/June 2011}

Published online: 24 March 2011

(C) Springer Science+Business Media, LLC 2011

Daniel J. Mahoney, The Conservative Foundations of the Liberal Order: Defending Democracy against Its Modern Enemies and Immoderate Friends. Wilmington, DE: ISI Books, 2011. \$26.95. 224pp.

The future of democratic order, Daniel Mahoney argues, depends on how well all citizens of democracy understand its historical, political, spiritual, and cultural foundations. He rejects both the utopianism and despair of intellectuals whose grasp of these foundations is poorly understood, offering instead a rousing defense of a "conservative-minded" liberalism.

Lawrence A. Scaff, Max Weber in America. Princeton: Princeton University Press, 2011. \$35.00. 326pp.

Scaff, professor of political science and sociology at Wayne State University, uses Max Weber's (and his wife, Marianne Weber's) visit to America in 1904 to ask "What does Weber make of this most essential tension between the demands of a certain kind of moral life and the competing demands of the "capitalist spirit?" Along the way readers are treated with an extraordinary array of details about the Webers' visit and the posthumous reception and interpretation of Weber in American social science.

Karen Sternheimer, Celebrity Culture and the American Dream: Stardom and Social Mobility. New York: Routledge, 2011. \$29.95. 298pp.
Sternheimer, who teaches sociology at the University of Southern California, offers a compelling narrative that reveals the many connections between Hollywood and Americans' self-understanding of social mobility and success. Although the rise from obscurity to fame for the vast majority may be mostly untrue, the belief in it is not.

C.J. Chivers, The Gun: The AK-47 and the Evolution of War. New York: Simon and Schuster, 2010. \$28.00. 496pp.

Chivers, former Marine, war correspondent, and military historian, has literally reframed our historical understanding of war and terror through the barrel of a gun. His history of the development of the AK-47 also reveals the relative lack of imagination in the American development of such weapons and the cost borne by American soldiers in particular in Vietnam as a result.

Kay S. Hymowitz, Manning Up: How the Rise of Women Has Turned Men into Boys. New York: Basic Books, 2011. \$25.99. 248pp.

Hymowitz, a senior fellow at the Manhattan Institute, identifies "pre-adulthood" as potentially a lifetime stage in maturation among American males. Her work resonates with others who have analyzed the economic and cultural factors that have challenged the development of male identity over the past quarter century. 